\title{
Arsenic Contamination in Ground Water in Bangladesh
}

\author{
— A Study on Taranagar Village
}

\author{
Wardatul Akmam* and Md. Fakrul IsLAm**
}

\begin{abstract}
Bangladesh is well known for her natural disasters such as floods and cyclones. Although Bangladesh has a higher amount of water per capita than most countries in the world, she often suffers from water shortages and droughts. Since the 1980s, groundwater (of hand tube wells) has been used for drinking and cooking all over the country to avoid water borne diseases. However, since 1993 tube wells in most parts of Bangladesh have become contaminated with high amounts of arsenic $(0.05 \mathrm{mg} /$ liter). In this paper the water situation of a village (Taranagar) severely affected by the arsenic problem is discussed based on a survey conducted in 2005. High levels of arsenic contaminated more than $97 \%$ of tube wells in this village. More than $90 \%$ of all households had patients with arsenicosis, five patients had already died. However, the villagers still remained almost without any effective alternative for a safe water source. The efforts of the Department of Public Health Engineering (DPHE) to install ring wells proved to be futile, as it was not possible to dig the wells according to the guidelines, and the water of these ring wells had bad odors. The paper concludes by urging all concerned to provide safe water to the people of Taranagar village.
\end{abstract}

Keywords: Arsenic contamination, Ground water, Level of arsenic awareness, Arsenic mitigation

\section{Introduction}

Life without water is impossible. Sufficiency of water is essential for the very maintenance of life on the one hand and on the other, excess of water often causes disaster and huge loss of life and property. In a world where scarcity of water is the most common problem, Bangladesh is one of the few fortunate countries with high per capita water. However, Bangladesh is still one of those countries that suffer most from socio-economic, environmental and health problems that emanate from water related causes. In this paper, we reflect on the socioeconomic and water-related scenario observed in a village named Taranagar, emphasizing the problem of arsenic contamination in ground water.

Bangladesh is a deltaic country, the land of which has been formed by the sediments borne by many rivers originating in other countries (mainly India and Nepal). These rivers are crisscrossed allover the land and ultimately fall into the Bay of Bengal. Most of the land is less than 5 meters above the sea level. The major area covered by forests is the Sundarbans, situated along the south west of the country, which is the largest mangrove forest in the world. Before going on to discussions specifically on Taranagar, we would like to focus briefly on the sources and uses of

* Associate Professor, Department of Sociology, University of Rajshahi, Bangladesh. E-mail : akmamprottoya@ hotmail.com

** Associate Professor, Department of Social Work, University of Rajshahi, Bangladesh. E-mail : hiraharati@yahoo.com

Received: 19 January 2007 Accepted: 5 August 2007

(C) 日本地域学会 (JSRSAI) 2007 
water along with some water related problems in Bangladesh.

\section{Sources, Uses and Problems Related to Water}

Rivers are the most important source of water in Bangladesh. The three largest rivers of country are the Padma (which has its upstream in India, known as the Ganges), the Jamuna, and the Meghna [13]. Depressions (known as Beel, Haor, Baor etc.) and ponds also are important sources of water in Bangladesh. Rainfall in the country varies in different areas from 1,200 mm/ year on the west to $4,000 \mathrm{~mm} /$ year in some areas of the east. On an average it contributes about 203 million acre-feet (MAF) of water each year. Mainly for irrigation and drinking/cooking purposes about 25.7 billion cubic meters of ground water is extracted each year through shallow tube wells, deep tube wells and other types of tube wells [13]. The Bay of Bengal is the only source of saline water in Bangladesh.

Besides the use of water for drinking and other mundane necessities, people in Bangladesh use water for irrigation, manufacturing (industries), fishery, and producing electricity. Rivers and the Bay of Bengal provide the most widely used means of transportation. Different categories of navigation waterways in Bangladesh add up to nearly $800 \mathrm{~km}$ [13].

Various irrigation and flood control projects e.g., the Ganges-Kobadak Project, the Muhuri Irrigation Project, the Meghna-Dhonogoda Project, the Coastal Embankment Project etc. [13] had

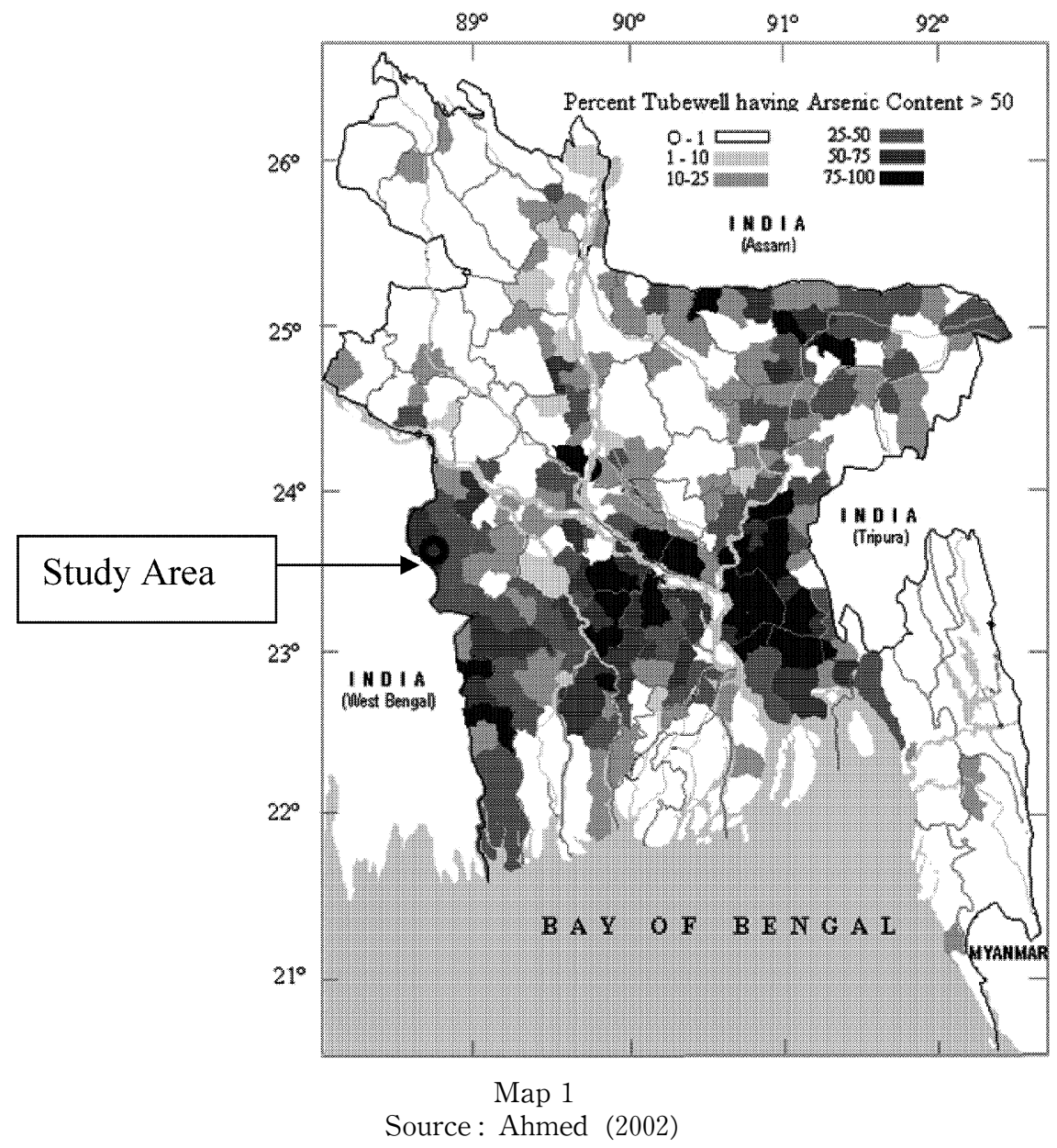


caused great environmental and socio-economic problems-rivers becoming dead, water logging, flash floods, droughts, navigation problems, loss of fishery etc. Flooding in Bangladesh at present is man-made to a large extent-construction of many roads and highways without leaving sufficient room for water drainage, and abrupt release of river water at the up stream by India cause severe flooding and disaster. Withdrawal of water at the up stream by India brings about droughts in the dry season. Moreover, lowering of water table (resulting from over-extraction of ground water) has caused landslides underground creating cracks visible on the earth's crust in the southwest region of the country (Jessore District). In this region, because of the Farakka Barrage at the upstream, surface water is not available for irrigation and the farmers are compelled to use underground water for that purpose [7]. Furthermore, water pollution resulting from human activities contributes to deterioration of water quality and human health and to loss of fishery. Water bodies in Bangladesh are polluted in various ways-

(1) Human waste is allowed to go directly into the rivers/ponds etc.

(2) Chemical fertilizers and pesticides used for agriculture go into the water bodies with rainwater.

(3) Untreated industrial wastes also go into the water bodies causing pollution and making the water unhealthy for fishery and other marine life [12].

On top of the water-related problems mentioned above, arsenic contamination in ground water emerged as the most alarming issue related to water supply and management in Bangladesh in the early 1990s. Irrespective of regional differences, tube wells have been the most trusted (as safe) and widely accepted source of water for drinking and cooking in the country. As tube wells are easy to install and maintenance cost is almost nil, almost every household enjoy having a tube well within its home compound. However, since 1993, tube well water was gradually being discovered to be containing arsenic at higher levels than is acceptable (50 micrograms/liter for Bangladesh and 10 micrograms/liter for World Health Organization).

Arsenic (As) is a semi-metal without any taste or odor. Inorganic arsenic has two main forms, arsenite (As III) and arsenate (As V), the former of which is the most toxic when dissolved in water [9]. Adverse effects of arsenic can be observed on virtually all the systems of the body and on mental functions as well [16]. The mostly recognized symptoms of arsenic toxicity in Bangladesh are melanosis, keratosis, hyperkeratosis, skin cancer, lung cancer, cancer of the internal organs and gangrene, which may appear after continuous ingestion of arsenic contaminated water for a period of 7-10 years. Arsenicosis can be transmitted to the fetus within the mother's womb. Findings of a study by Chen et al. [5] show that consumption of water contaminated with arsenic at the level of $.01 \mathrm{mg} /$ liter/day would carry the risk of ending up with cancer of the lung, bladder, kidney, liver and skin at the rate of $1.2 / 1,000,1.2 / 1,000,0.4 / 1,000,0.4 / 1,000$, and 3/1,000 for men and $1.3 / 1,000,1.7 / 1,000,0.5 / 1,000,0.4 / 1,000$, and $2.1 / 1,000$ for women. Exposure to arsenic $(0.5 \mathrm{mg} /$ liter) carries a combined cancer risk of 13/1,000 [14].

Mainly hand tube wells installed in the flood plains and the deltaic plains, which comprise more than $72 \%$ percent of the total area in Bangladesh, are affected by arsenic contamination [3]. According to a study carried out by DPHE and BGS [8] tube wells in 53 out of 64 districts have been affected and at least 35 million people are exposed to arsenic-related diseases (arsenicosis) and an untimely and painful death [2] making this "the largest mass poisoning in history" [14]. Hundreds have already died of arsenic poisoning and thousands are now suffering from arsenicosis. Currently a major responsibility of the government of Bangladesh and the international community is to make some arrangements for these affected people to get access to safe water immediately. The alternative options of safe water that are being proposed include pond sand filters, rainwater harvesting, dug wells, water filters (to remove arsenic) and deep tube wells. 


\section{Methodology}

This paper is principally concerned with the water scenario, with special emphasis on the arsenic-related situation in a village named Taranagar (location shown by a small circle in Map 1). We have carried out a social survey in Taranagar (during May-June, 2005) to know about the water-related situation in the village-especially the arsenic related situation. Heads of households and female heads of households of 175 out of 850 households (15\%) were interviewed. The respondents were selected through simple random sampling. The data were processed and analyzed using SPSS software.

\section{Socio-economic Condition in Taranagar}

Taranagar is a village with an area of 488 acres and an estimated population of 3,500 people. There were around 850 households with an average of 4.12 persons. The infrastructure and roads are not at all developed. There are no concrete roads. However, there is a high school as well as a mosque. The village does not have any recognized cottage industry except for the seasonal production of molasses (Patali Gur) from the sap of date trees.

It is revealed from the data that forefathers of more than $25 \%$ of the households had come to live in the village from other places. Many of these forefathers had come from neighboring India.

\section{Income}

Table 1 portrays the income levels of the Taranagar residents. Their average monthly income was around Taka 3,557.14. The poor financial situation of the villagers can be well apprehended by the fact that almost $65 \%(n=113)$ of the households earned only Taka 3,000 or less per month (1US $\$=69$ Taka) and $47(26.86 \%)$ earned Taka 3001-6000. This gives us an idea about the income level of the people in a nutshell.

\section{Education}

We calculated the average schooling years (ASY) of all the members of the respondents' households (those aged 7 and above) in order to have an overall idea of educational situation in the

Table 1 Monthly Income of the Respondents

\begin{tabular}{|c|c|c|}
\hline Income Level (in Taka) & No. of Respondents & Percentage \\
\hline $0-3,000$ & 113 & 64.6 \\
$3,000-6,000$ & 46 & 26.3 \\
$6,000-10,000$ & 14 & 8.0 \\
$>10,000$ & 2 & 1.1 \\
\hline Total & 175 & 100.00 \\
\hline
\end{tabular}

Table 2 Average Schooling Years of Respondents' Households

\begin{tabular}{|c|c|c|}
\hline Average Schooling Years & Frequency & Percentage \\
\hline $0-3$ & 63 & 36.00 \\
$3-6$ & 63 & 36.00 \\
$6-10$ & 43 & 24.60 \\
$>10$ & 6 & 3.40 \\
\hline Total & 175 & 100.00 \\
\hline
\end{tabular}


Table 3 Occupation of the Respondents' Households

\begin{tabular}{|c|c|c|}
\hline Occupation & Frequency & Percentage \\
\hline Agriculture & 37 & 21.10 \\
\hline Agriculture and Business & 29 & 16.60 \\
\hline Agriculture, Business and Labour & 2 & 1.10 \\
\hline Agriculture, Business and Services & 1 & .60 \\
\hline Agriculture and Labour & 59 & 33.70 \\
\hline Agriculture and Services & 11 & 6.30 \\
\hline Business & 12 & 6.90 \\
\hline Labour & 20 & 11.40 \\
\hline Services & 2 & 1.10 \\
\hline Services and Labour & 2 & 1.10 \\
\hline Total & 175 & 100.00 \\
\hline
\end{tabular}

village. The findings show that the mean average schooling years of respondents' households was 4.49. Thirteen $(7.43 \%)$ of the households had 0 ASY, meaning that none in their households had completed even a single year in school. However, as Table 2 portrays, $28 \%(n=49)$ of the households had an ASY of 6.01 years or more, which is quite high considering Bangladesh standards.

\section{Occupation}

Table 3 portrays the occupational situation of the respondent households. It is observed that most households $(n=139,79.4 \%)$ were principally or partially dependent on agriculture. The main crops of the area were paddy, wheat, potato, onion, garlic, vegetables, jute, sugar cane, banana etc. It is to be mentioned here that farmers who worked on their own land and/or hired others' labor for cultivating the same were considered engaged in agriculture. The laborers were mostly engaged in agricultural jobs. Table 3 also shows that most households were dependent on more than one occupation $(n=104,59.43 \%)$.

\section{Water Related Situation in Taranagar}

Taranagar is situated in Bagoan Union of Meherpur Thana within Meherpur District. Meherpur district is situated within the moribund delta region of Bangladesh. The area is a little less than 9 meters above sea level. Average yearly rainfall in the area is also not very high (around $1,500 \mathrm{~mm}$ ). There is no river flowing adjacent to Taranagar. However, there is a big beel (depression) within the village, which contains water all year round. There are about 14 ponds in the village. Five of these become totally waterless in the dry season. The other nine ponds contain water all year round, although the amount decreases significantly in the dry season. Water of the beel and the ponds is still free of the dangers of arsenic.

During the survey, people of Taranagar informed that they used 85 shallow tube wells for irrigation purposes, the depth of which varied from 150-190 feet (46-58 meters). These shallow tube wells were operated during October-May. All were dangerously contaminated by arsenic. There were no deep tube wells installed within the village. During the dry season in the months of March-April, beel water was used to some extent in adjacent areas for irrigation purposes.

\section{Arsenic-related Condition in Taranagar}

Although Meherpur district in general has $50-75 \%$ of the tube wells with arsenic content above $0.05 \mathrm{mg} /$ liter (see Map 1), 97.14\% of the tube wells in this particular village had arsenic content above that level. Five people of the village had already died of arsenicosis and almost all 
Residential Area of Taranagar Village

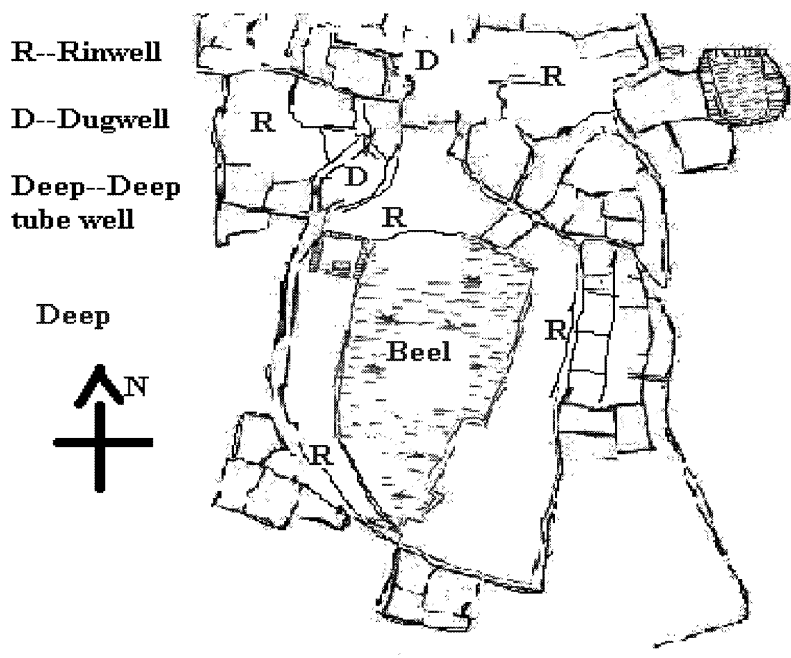

Map 2

Table 4 Kind of Water Used for Drinking

\begin{tabular}{|l|c|c|}
\hline Water used for drinking & Frequency & Percent \\
\hline Dug well water & 50 & 28.6 \\
Filtered tube well water & 1 & 0.6 \\
Ring well water & 42 & 24.0 \\
Tube well water & 82 & 46.8 \\
\hline \multicolumn{1}{|c|}{ Total } & 175 & 100.0 \\
\hline
\end{tabular}

households had at least one patient.

Findings of the survey reveal that six (3.43\%) heads of households did not have their tube wells tested for arsenic. Among those who had their tube wells tested, 92.69\% $(n=157)$ were found contaminated. More than $52 \%$ of the households were using dug well $(28.6 \%, n=50)$ and ring well $(24 \%, n=42)$ water for drinking, in spite of bad odor in ring well water. Many could not use dug well/ring well water for cooking, as the water source was quite far from their residence (see Map 2). Eighty-two (46.8\%) households still used tube well water for drinking and cooking. Thus notwithstanding having patients in their households, a significant proportion of households in Taranagar continued to drink from contaminated tube wells. The reasons they pointed to were that (a) they were not willing to change their habit of drinking tube well water (specially for reasons of taste and odor) ; and (b) acceptable alternative sources of drinking water within short distance was not available.

\section{Awareness Level of the Respondents}

The arsenic-related description of Taranagar given above called for immediate awareness building among the inhabitants of the village. The villagers were exposed to arsenic-related information disseminated through the media (radio, TV and newspapers). The DPHE (Department of Public Health Engineering) and NGOs working in the area (Kranti, EADS and Podokkhep) also were involved in awareness building programs in Taranagar. Under the projects 
Table 5 Awareness Level of the Respondents

\begin{tabular}{|c|c|c|}
\hline Awareness Level & Frequency & Percentage \\
\hline 1.00 & 21 & 12.0 \\
2.00 & 58 & 33.1 \\
3.00 & 36 & 20.6 \\
4.00 & 48 & 27.4 \\
5.00 & 12 & 6.9 \\
\hline Total & 175 & 100.0 \\
\hline
\end{tabular}

undertaken, all tube wells in the area were to be tested and the users were to be informed about the arsenic content found in the water of their tube wells. However, as we have seen, even in 2005 some tube wells had not been tested.

A fully aware person (of the arsenic problem) must know how dangerous it is to drink arsenic-contaminated water, what the mitigation steps are and actually enact this knowledge by alteration of budget, taste, habit, and even daily schedules, if necessary [16]. In order to measure awareness level of the respondents in Taranagar, a five-point scale was developed. Table 5 depicts awareness level of respondents. Twenty-one (12\%) of the respondents had achieved a very low level of awareness (level 1), and only 12 (6.9\%) had achieved the highest level (Level 5). The percentage of respondents achieving the level of 4 was $27.4 \%(n=48)$. Chi-square tests show that awareness level was significantly associated with factors such as average schooling years $\left(\chi^{2}=\right.$ 5.232 ; d.f. 1 ; significance level: 0.022$)$, income $\left(\chi^{2}=7.006\right.$; d.f. 1 ; significance level: 0.008$)$, occupation $\left(\chi^{2}=20.937\right.$; d.f. 1 ; significance level : 0.000$)$ and patient in household $\left(\chi^{2}=3.734\right.$; d.f. 1 ; significance level: 0.053$)$. Thus it can be said that special attention should be given in raising awareness among households with lower average schooling years, with lower income, those engaged in selling labour, and those without patients in their households.

The inhabitants of Taranagar did not experience any of the social problems (e.g., ostracism, marriage problems, being abandoned by family and community members, not being able to attend gatherings/school etc.) that are usually attached to the arsenic crisis. The reason for this may have been that almost everyone in the village were more or less affected, having patients in their households. As the awareness level was relatively high, the superstition that arsenicosis was a contagious disease was discarded by the villagers.

\section{Willingness to Pay}

Willingness to pay (per month) in order to get safe water could be regarded as a criterion for assessing awareness level among the respondents. Prior to arsenic poisoning in ground water people in Bangladesh used tube well water almost free of cost. In spite of such type of mind-set we find that the average amount of money the respondents were willing to pay was Taka 59.71. Table 6 shows in detail the amount of money respondents were willing to pay per month in order to get safe water. Only one respondent $(0.6 \%)$ was not willing to pay any money to get safe water. Most respondents $(n=153,87.4 \%$ ) were willing to pay up to Taka 50 per month and $11.9 \%$ $(n=21)$ were willing to pay above Taka 50 per month.

\section{Willingness to Donate for Establishing or Buying Safe Water Sources}

Respondents were asked about the amount of money they were willing to donate in order for establishing community based safe water sources. The average amount of money the respondents were willing to donate was Taka 662.86. All the respondents agreed to donate at least Taka 500 for the establishment of safe water sources. The highest amount of money the respondents were 
Table 6 Willingness to Pay (per month)

\begin{tabular}{|c|c|c|}
\hline Willingness to Pay (Taka) & Frequency & Percentage \\
\hline 00 & 1 & 0.6 \\
$0-50$ & 153 & 87.4 \\
$50-100$ & 16 & 9.1 \\
$100-200$ & 3 & 1.7 \\
$200-300$ & 2 & 1.1 \\
\hline Total & 175 & 100.0 \\
\hline
\end{tabular}

Table 7 Willingness to Donate for the Establishment of Safe Water

\begin{tabular}{|c|c|c|}
\hline Willingness to Donate (Taka) & Frequency & Percentage \\
\hline 00 & 0 & 00.0 \\
$00-500$ & 160 & 91.4 \\
$500-1,000$ & 6 & 3.4 \\
$1,000-2,000$ & 5 & 2.9 \\
$2,000-5,000$ & 4 & 2.3 \\
\hline Total & 175 & 100.0 \\
\hline
\end{tabular}

Table 8 Willingness to Walk to Bring Safe Water

\begin{tabular}{|c|c|c|}
\hline Willingness to Walk (Minutes) & Frequency & Percentage \\
\hline 00 & 12 & 6.9 \\
$00-05$ & 8 & 4.6 \\
$5-10$ & 3 & 1.7 \\
$10-15$ & 21 & 12.0 \\
$15-20$ & 131 & 74.9 \\
\hline Total & 175 & 100.0 \\
\hline
\end{tabular}

willing to donate was Taka 5,000.

\section{Willingness to Walk}

It is usually assumed that the amount of water needed per person for drinking and cooking is five liters. If the source of water is far away from the home compound, a lot of time and labour is required for carrying water, which often makes the task impossible to execute. In Bangladesh, procuring water for the family is considered 'women's work.' Therefore, the female heads of household were asked about the distance they were willing to walk to procure safe water. Only $6.9 \%$ of the respondents $(n=12)$ were unwilling to walk at all. Most surprisingly almost $75 \%$ of the respondents were willing to walk a distance of even 20 minutes to bring water.

\section{Inter-relationship between Socioeconomic and Arsenic-related Variables}

Chi square tests have been carried out to see if different socio-economic variables (e.g. income, land holding, ASY, etc.) and arsenic-related variables (having patients in household, willingness to pay, etc.) were inter-related (see Table 9). We find that having patients in household was not 
Table 9 Relationship between Variables

\begin{tabular}{|c|c|c|c|c|c|c|c|c|c|c|c|c|}
\hline $\begin{array}{c}\mathrm{L} / \mathrm{P} \\
\chi^{2}\end{array}$ & $\begin{array}{c}\mathrm{I} / \mathrm{P} \\
\chi^{2}\end{array}$ & $\begin{array}{c}\mathrm{ASY} / \mathrm{P} \\
\chi^{2}\end{array}$ & $\begin{array}{c}\mathrm{L} / \mathrm{WP} \\
\chi^{2}\end{array}$ & $\begin{array}{c}\mathrm{L} / \mathrm{D} \\
\chi^{2}\end{array}$ & $\begin{array}{c}\mathrm{E} / \mathrm{WP} \\
\chi^{2}\end{array}$ & $\begin{array}{c}\mathrm{E} / \mathrm{D} \\
\chi^{2}\end{array}$ & $\begin{array}{c}\mathrm{I} / \mathrm{WP} \\
\chi^{2}\end{array}$ & $\begin{array}{c}\mathrm{I} / \mathrm{D} \\
\chi^{2}\end{array}$ & $\begin{array}{c}\mathrm{P} / \mathrm{WP} \\
\chi^{2}\end{array}$ & $\begin{array}{c}\mathrm{P} / \mathrm{D} \\
\chi^{2}\end{array}$ & $\begin{array}{c}\mathrm{WE} / \mathrm{WW} \\
\chi^{2}\end{array}$ & $\begin{array}{c}\mathrm{I} / \mathrm{WW} \\
\chi^{2}\end{array}$ \\
\hline 0.107 & 0.040 & 0.327 & 13.225 & 16.205 & $\begin{array}{c}8.596 \\
\mathrm{SA}\end{array}$ & $\begin{array}{c}14.946 \\
\mathrm{SA}\end{array}$ & $\begin{array}{c}10.179 \\
\mathrm{SA}\end{array}$ & $\begin{array}{c}24.046 \\
\mathrm{SA}\end{array}$ & $\begin{array}{c}0.269 \\
\mathrm{NSA}\end{array}$ & $\begin{array}{c}0.036 \\
\mathrm{NSA}\end{array}$ & $\begin{array}{c}5.084 \\
\mathrm{SA}\end{array}$ & $\begin{array}{c}8.632 \\
\mathrm{SA} \\
(0.01)\end{array}$ \\
$\mathrm{NSA}$ & $\mathrm{NSA}$ & $\mathrm{NSA}$ & $\begin{array}{c}\mathrm{SA} \\
(0.001)\end{array}$ & $(0.001)$ & $(0.01)$ & $(0.001)$ & $(0.01)$ & $(0.001)$ & & & \\
\end{tabular}

* Degree of Freedom $=1$ in all cases

Acronyms of abbreviations: $\mathrm{L}=$ ownership of land, $\mathrm{P}=$ having patient in household, ASY $=$ average schooling years of household, $\mathrm{I}=$ income, $\mathrm{WP}=$ willingness to pay (per month) to get safe water, $\mathrm{D}=$ willingness to donate at the initial stage for establishment of safe water source, $\mathrm{E}=$ education of head of household, WE=education of female head of household, WW= willingness to walk.

associated with land ownership or monthly income. Average schooling years in family (ASY), however, was associated with having patients in households. Willingness to pay (WP) and willingness to donate for the purpose of establishing safe water source at a close distance (D) were very significantly associated with land holding and income. Education of respondents (male heads of households) had very significant association with both (WP) and (D). Having patients in household, however, was not associated with (WP) or (D).

In rural Bangladesh, having to go out of the home compound to fetch water is a symbol of lower social status. For this reason, we observe that income and willingness to walk to fetch water were significantly associated. The higher the income, the lower the willingness to walk. Number of schooling years of the female respondents did not significantly affect their willingness to walk (WW).

\section{Arsenic Mitigation in Taranagar}

Even though the level of awareness seems to be somewhat satisfactory, most people in Taranagar still did not know many aspects of the arsenic problem, especially regarding its mitigation. The affected people wanted to drink from safe water sources, but they did not have a clear idea about the available options. Although the NGO workers informed people whether their tube wells were safe or not by painting them either red or green (red for not-safe, green for safe), they were not able to make them understand the alternative sources of water from which they could get safe water e.g. through treating surface water using pond sand filters, rainwater harvesting and filtering arsenic contaminated water. Almost half of the population in Taranagar (47.42\%) was still drinking water from danger marked tube wells. Some people who were conscious were trying to find safe water sources. They brought water (just for drinking, but not for cooking although they knew that arsenic is not removed even after boiling the water) on foot from two old renovated dug wells that were situated far away from their houses. These dug wells were privately owned and sometimes the owners did not allow outsiders to procure water from those dug wells to maintain privacy.

The Government institution that is responsible for providing the arsenic affected people with safe water is The Department of Public Health Engineering (DPHE). The Executive Engineer of this office has informed that the government has given them a few ring wells to be installed at the arsenic affected sites as per requests made by the Chairman of the Union Parishad (local administrative body). There is information that as the current Chairman was not an inhabitant of Taranagar, he, instead of establishing the wells in Taranagar, had established them in his own village, which is not so severely affected. A few ring wells that had been established in Taranagar had proved to be either not feasible or unusable, as excavation of ring wells was a very dangerous job ; there was possibility of death of the mason. Besides, drinkable water was not available in the well during all seasons and there were also complains of bad odor in ring well water. 
Table 10 Respondents' First Choice Regarding Alternative Option

\begin{tabular}{|c|c|c|}
\hline Options & No. of Respondents & Percentage \\
\hline Tap Water at Home & 55 & 31.43 \\
\hline Tap Water in walking Distance & 113 & 64.57 \\
\hline Purified Dug well/Pond Water & 5 & 2.86 \\
\hline Filters & 2 & 1.14 \\
\hline Total & 175 & 100.00 \\
\hline
\end{tabular}

Although no deep tube well had been installed in Taranagar, there was one in an adjacent village. During the period the deep tube well was in operation for irrigation, some people of Taranagar brought water from that deep tube well. Water of that deep tube well had been found to be free of arsenic. The rest of the year these people used arsenic contaminated tube well water for drinking and cooking.

The respondents' first choice regarding alternative safe water option was for the most part tap water at home, or at a close distance (see Table 10). So, provisions can be made to supply water at certain points of the village, from which people can procure water within a short distance from their houses. However, there remains the problem of finding a proper layer for installation of the deep tube well and also the possibility that deeper aquifers may also become contaminated. Another possible option could be to use the water of the beel that has water all year round. An ultra violet disinfection plant can be used to purify the water of the beel and through pipeline system water could be supplied to various points of the village. This plant has the capacity of serving 800 households and the establishment cost is just Taka 1,00,832 [15]. With a pipeline system the cost might be double or triple that amount.

Pond sand filters are another option, which the people might adopt at a smaller scale. It has been mentioned earlier that there were 14 arsenic-safe ponds in the village, of which 9 contained water all year round. These ponds were used for fishery. If the owners were given the amount of money they earn through fishery, these owners could think about renovating these ponds for drinking purposes and install pond sand filters. It costs less than Taka 1,000 to establish a pond sand filter and it can serve 20 households [1].

Rainwater harvesting is another alternative method for procuring arsenic safe water. Rainfall in Taranagar is on an average around 1,500 $\mathrm{mm}$ per year. This is not sufficient for all year round water supply, but it could supply drinking and cooking water partially, during the rainy season.

Filtering of arsenic contaminated water is another option, about which as it seems the respondents of Taranagar had never heard of. Water experts usually discourage use of filters as a safe water option in the long run, as generation of sludge is involved in this method. However, for an emergency situation that we observe in Taranagar, the people should be supplied with these filters so that they can get arsenic free water immediately. The procedure followed by Barendra Advancement Integrated Committee (BAIC) in Chapai Nawabganj in distributing filters can be imitated in Taranagar. BAIC distributed filters among the worst affected people in the region on the condition that they will pay the money back to the NGO in monthly installments [4]. This money was deposited in a bank account to be used for buying some more filters and given to other affected households. One popular brand of arsenic removing filter is known as SONO Filter, which the US Environment Protection Agency (EPA) has recommended as safe to use. According to the EPA, use of this filter would not cause any significant harm to the environment even if it were used for a long time.

Thus far we have focused mainly on the drinking water scenario of Taranagar village. In order to live we must also grow food to feed upon. The inhabitants of Tarangar relied on shallow 
tube wells for irrigation. Research is being carried out and in some of these research works it has been found that high amounts of arsenic have been found in grains and vegetables. There is possibility that the inhabitants of Taranagar are being poisoned by arsenic not only through drinking and cooking water, but also through eating food poisoned by arsenic contaminated irrigation water.

\section{Conclusion}

In this paper we have tried to focus in brief on the water scenario in a village named Taranagar in Meherpur district, which is severely affected by arsenic in ground water. Although Bangladesh has abundance of water during the rainy season causing floods, farmers are compelled to use groundwater for irrigation during the dry season. People were made habituated to drink groundwater to be safe from water borne diseases during the 1970s and 1980s-but to their surprise, this groundwater was found to be poisoned by arsenic, leading them to untold suffering and death. Using data from a survey carried out in Taranagar during May-June, 2005, we have pointed out the water situation existing in this village and the necessity to save the people by providing them with alternative and acceptable means of safe drinking (and cooking) water. Moreover, the people are to be motivated to refrain from using groundwater as much as possible. As Bangladesh is basically an agrarian country, governments in power almost at all times (during the last 200 years), including the present one have tried to emphasize rural development, trying to discover new mechanisms for fast and sustainable development of the rural people [6]. Besides, many non-government organizations (NGOs) have come forward to up lift the socio-economic conditions of the rural poor [10]. However, the endeavor to bring the rural poor out of poverty cannot be successful, unless the basic necessity of safe water can be assured for them. Therefore, all those concerned for the healthy living of the rural people must take immediate action to ensure that the arsenic-affected people in Bangladesh have the opportunities to collect drinking and cooking water from safe water sources. For the people in Taranagar, measures must be taken immediately to supply them with SONO filters (one filter is sufficient for supplying safe water for drinking and cooking water for five households) and explain to them properly, the process of operation. Time is running out. So we must act now.

\section{References}

[1] Ahmed, Hasan Sharif (editor), Combating a Deadly Menace: Early Experiences with communitybased Arsenic Mitigation project in Bangladesh-June1999-June 2000. Dhaka: BRAC, 2000.

[2] Ahmed, Kazi Matin, "Arsenic contamination in groundwater and a review of the situation in Bangladesh." In Groundwater Resources and Development in Bangladesh: Background to the Arsenic Crisis, Agricultural Potential and the Environment, Dhaka: UPL, 2003, pp. 395-464.

[ 3 ] BAMWSP, "National Policy for Arsenic Mitigation in Bangladesh," In Home page of Bangladesh Arsenic Mitigation and Water Supply Project. Internet communication on March 10, 2005 at http://www.bamwsp.org/Arsenic\%20Policy\%202004/national policy2004.pdf.

[4] Barendra Advancement Integrated Committee (BAIC), BAIC Annual Report 2003-2004. Chapai Nawabganj: BAIC, 2004.

[ 5 ] Chen, C.J., Hsueh, Y.M., Chiou, H.Y., Hsu, Y.H., Chen, S.Y., Horng, S.F., Liaw, K.F. and Wu, M.M., "Human Carcinogenicity of Inorganic Arsenic," In Arsenic Exposure and Health Effects, C.O. Abernathy, R.L. Calderon and W.R. Chappell (eds.), London: Chapman and Hall, 1997.

[6 ] Chowdhury, Anwarullah, Agrarian Social Relations and Development in Bangladesh, New Delhi: Oxford and IBH Publishing Co., 1982.

[7] Daily Amar Desh (a national daily newspaper published in Bangla), 17 June, 2005. 
[8] Department of Public Health Engineering (DPHE), Government of the People's Republic of Bangladesh and British Geological Survey (BGS), UK (2000). Groundwater Studies of Arsenic Contamination in Bangladesh: Final Report Summary. [online document] http://www. bgs.ac.uk/arsenic/Bangladesh/home.html. [June 25, 2000].

[ 9 ] HVR Arsenic Project, "What is Arsenic?," Internet communication, 23 May 2000, at http://www. hvr.se/nov97/arsenic.html.

[10] Islam, Md. Rabiul, "Rural Social Services Program in Bangladesh: Development Initiatives and Challenges,” Social Science Journal, Vol. 8, 2003, pp. 199-216.

[11] Khan, Md, Amjad Hossain, "Environmental Aspects of Surface Water Development Projects in Bangladesh" In Environment and Development in Bangladesh Vol. 2 ; A, Atiq Rahman, Saleemul Huq, Raana Haider and Eirik G. Jansen (eds.) ; Dhaka: University Press Limited; 1994, pp. 102-130.

[12] Rahman, A., Atique and Saleemul Huq, "Environment and Development Linkages in Bangladesh," In Environment and Development in Bangladesh Vol. 1; A, Atiq Rahman, Saleemul Huq, Raana Haider and Eirik G. Jansen (eds.) ; Dhaka : University Press Limited ; 1994, pp. 27 37.

[13] Rashid, Haroun Er, "River, Water and Wetlands," In Bangladesh Environment : Facing the $21^{\text {st }}$ Century. Philip Gain (ed). Dhaka : Society for Environment and Human Development ; 1998, pp. $170-171$.

[14] Smith, Allan H., Elena O. Lingas and Mahfuzar Rahman. The Bangladesh Well Water Arsenic Calamity. An article accepted for publication in WHO Bulletin collected through personal communication with Dr. Allan Smith. 2000.

[15] Waterhealth International Inc, "Products," Internet communication on May 27, 2001 at http:// www.waterhealth.com.cws.html.

[16] Zuberi, M.I., “Arsenic Mitigation through AMP-Christian Aid Support: Awareness, Communication and Scaling Up,” An assessment report commissioned by AMP-Christian Aid (UK), 2003. 